\title{
REFERENCES
}

Bartelli (1938-39).-Abstr: Zentralb., Vol. XLII, p. 206.

BüCKLERS (1935).-Klin. Monatsbl, f.,Augenheilk., Vol. XCV, p. 393.

DUKE-ELdER (1940).-Text-book of Ophthalmology, p. 2942.

DUTEMPS, DuPUy (1914).-Ann. d'Ocut., Vol. CLI, p. 161.

GRIMMINGER, W. (1924).-Zeitschr.f. Augenheilk., Vol. LIII, p. 41.

KEY and RETZIUS (1870).-Quoted by Eisler, Schieck and Brückner, Kurzes Handbuch., I, p. 139.

LIEBRECHT (1906).-Arch.f. Augenheilk., Vol. LV, p. 36.

(1912)-Arch.f. Ophthal., Vol. LXXXIII, p. 525.

LYNGAR, E. (1939) -Abstr. Zentralb., Vol. XLIII, p. 291.

MACKEnziE, W. (1930), - Treatise on Diseases of the Eye. Third Edition.

Paton, L. (1924).-Trans. Ophthal. Soc. U.K., Vol. XLIY, p. 110.

RIDDOCH and Goulden (1925).-Brit. Jl. Ophthal., Vol. IX, p. 209.

Simith, Priestrey (1884) - Trans. Ophthal. Soc. U.K.. Vol. IV, p. 271.

SYMonds, C. P. (1924).-Quart. Jl.Med., Vol. XVIII, p. 93.

Guy's Hosp. Rep., April 1923.

TUREen, L. L: (1941).-Abstr. Arch. of Ophthal., Vol. XXVI, p. 319.

UHTHOFF.-Graefe-Saemisch. Handbuch., Vol. XI, p. 1463.

Wilks (1859).-Guy's Hosp. Rep. Quoted by Symonds, 1924.

WolfF, E. (1940).-The Anatomy of the Eye and Orbit. Third Edition.

\section{A CASE SHOWING PARTIAL DEFICIENT FUSION OF A MAXILLARY PROCESS WITH LATERAL NASAL PROCESS ON ONE SIDE}

\author{
BY
}

\author{
G. E. DODDS
}

WEST AFRICAN MEDICAL SERVICE

By an odd coincidence $I$ saw the case here described just after I received the January number of the Journal containing an account of cases with malar bone deficiency. As I have access to a very limited literature here I am unable to say much about it.

The patient in this instance is an African baby girl, aged 3 months. The first child of healthy parents who state that there is no history of hereditary defects in the family.

The outstanding features on first viewing the patient were :

1. The distortion of the right nostril with a hiatus showing the interior of the nose-the cleft extending upwards to within about $1 \mathrm{~cm}$. of the inner canthus.

2. The abnormality of tbe inner canthus-wide obtuse-angled.

With more detailed examination the following additional abnormalities were noted: 
(a) Upper-lids-a small notch-coloboma-at junction of inner with outer two-thirds in each lid-lateral to the puncta.

(b) Right lower lid-normal lateral to the punctum while medial to this is a notch the inner side of which is continued in a straight line to the medial end of the upper.lid. No caruncle and doubtful plica semilunaris.

(c) On the inner side of the left medial canthus is a vertical hole; in appearance like the opening of a sinus. It was a blind shallow pit.

(d) The cleft or fissure extends from the lower and lateral margin of the right nasal bone to the point where normally the nostril joins

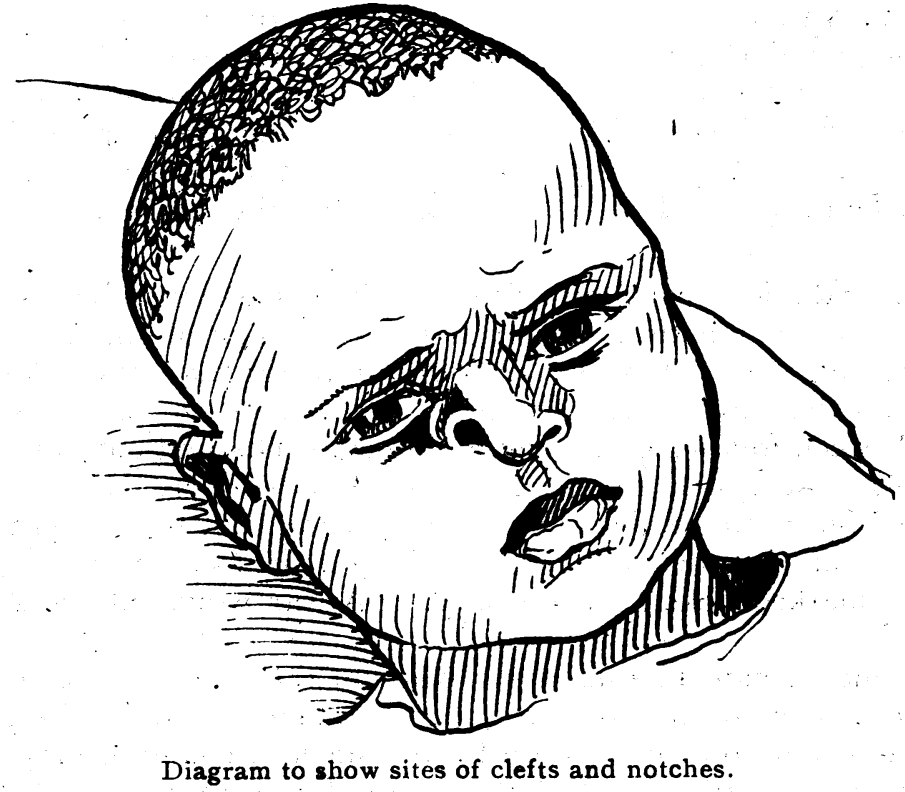

the lip. This is merely a cleft in the cartilagenous part of the nose. The surrounding bones appeared normal.

(e) Conduction of tears appeared to be normal.

(f) Eyes normal in every respect.

(g) Ears somewhat large and cup-shaped.

Two points of particular interest arise.

1. What is the significance of the blind pit in the skin on the inner side of the medial canthus? Any embryological explanation?

2. The treatment of this condition. As the completion of the nasal cleft would require a pedicle graft from the arm or forehead it was deemed advisable to wait as it was considered that there would be a better chance of success later on, Is this the correct attitude in cases of this nature? 